\title{
Pembuatan Sistem Informasi Irigasi dan Kebutuhan Air dengan Standar dan Mekanisme Akses Berbasis Infrastruktur Data Geospasial untuk Irigasi Pertanian di Kabupaten Karanganyar
}

\author{
Development of the Irrigation and Water Need Information System with Spatial Data Infrastructure- \\ Compliant Standards and Access Mechanisms for Agricultural Irrigation in Karanganyar \\ Dimas Uga Perceka ${ }^{1}$, Trias Aditya ${ }^{2}$ \\ ${ }^{1}$ Alumni Magister Teknik Geomatika, Departemen Teknik Geodesi, Universitas Gadjah Mada, Indonesia \\ ${ }^{2}$ Staf Pengajar Departemen Teknik Geodesi, Universitas Gadjah Mada, Indonesia
}

Penulis Korespondensi: Dimas Uga Perceka | Email: dimas.uga.perceka@mail.ugm.ac.id

Diterima (Received): 20/11/2020 Direvisi (Revised): 17/03/2021 Diterima untuk Publikasi (Accepted): 17/03/2021

\begin{abstract}
ABSTRAK
Manajemen irigasi diperlukan dalam mendukung tatakelola dan penentuan kebutuhan air, khususnya pada lahan pertanian. Manajemen irigasi tersebut dapat dioptimalkan dengan melakukan inventarisasi data irigasi di dalam sebuah web map. Inventarisasi data tersebut bertujuan agar skenario tukar guna data spasial khususnya terkait manajemen irigasi dapat berjalan optimal. Skenario tukar guna data dapat optimal apabila diseminasi informasi yang ada dapat saling terintegrasi. Permasalahan utama yaitu disem inasi informasi ataupun data terkait kebutuhan air untuk lahan pertanian ada pada sumber yang terpisah sehingga sulit untuk menganalisis hasil integrasi dari data tersebut. Permasalahan tersebut dapat diselesaikan dengan menyelaraskan data (curah hujan efektif, evapotranspirasi, porositas, total kehilangan air, efisiensi irigasi, petak irigasi, saluran irigasi dan petak irigasi) sehingga data dapat diintegrasikan dan dapat dimanfaatkan oleh pengguna. Pada tulisan ini dilakukan 5 tahapan kegiatan yaitu perencanaan dan pengumpulan data, analisis, desain sistem, implementasi dan evaluasi. Hasil yang didapat yaitu berupa web map yang digunakan untuk memfasilitasi ketersediaan dan akses data spasial yang di dalamnya terdapat data irigasi dan klimatologi. Dalam web map yang dibangun terdapat fasilitas-fasilitas diantaranya pembacaan data, penambahan data, pembaruan data, penghapusan data dan pengunduhan data. Web map yang dinamakan Sistem Informasi Irigasi dan Kebutuhan Air (SIRISKA) ini merupakan sebuah web map dinamis yang menggunakan fungsi Create Read Update and Delete (CRUD) ke basis data. Web map dibangun berdasarkan integrasi antara komponen back-end yang terdiri atas PostgreSQL (basisdata), PHP (server-side scripting), Apache (web server) dan komponen front end yang terdiri atas JavaScript, HTML dan CSS. Web map SIRISKA dievaluasi dengan beberapa parameter diantaranya efektifitas, kebergunaan, konsistensi, kejelasan arsitektural dan visual, dan kemampuan data sharing. Berdasarkan evaluasi tersebut dapat disimpulkan bahwa sistem informasi yang dibuat dapat memudahkan pengguna untuk melakukan tukar guna data dan mendapatkan informasi kebutuhan air irigasi untuk setiap petak irigasi.
\end{abstract}

Kata Kunci: Irigasi,Webmap, CRUD, Manajemen

\begin{abstract}
Irrigation management is essential to support the management and determination of water needs, especially on agricultural land. Irrigation management can be optimized by conducting an inventory of irrigation data on a webmap. This is intended so that the spatial data exchange scenario, especially related to irrigation management, can run optimally. The data exchange scenario can be optimal if the existing information dissemination can be integrated. Dissemination of information or data related to water needs for agricultural land is available in a separate source, making it difficult to analyze the results of the integration of these data. This problem can be solved by harmonizing data (effective rainfall, evapotranspiration, porosity, total water loss, irrigation efficiency, irrigation plots, irrigation canals and irrigation plots) so that data can be integrated and can be utilized by users. In this paper, 5 stages of activity were carried out, namely planning and data collection, analysis, system design, implementation and evaluation. The result of this research is a platform used to facilitate the availability and access of spatial data in the form of a website that contains irrigation and climatological data. The result of this paper is a webmap that is used to facilitate the availability and access of spatial data in the form of a website which contains irrigation and climatological data. In the webmap display there are facilities including reading data, adding data, updating data, deleting data and downloading data. The webmap, called SIRISKA (Irrigation Information System and Water Requirements), is a dynamic webmap that uses the CRUD (Create Read Update and Delete) function to the database which is an integration between Back-end components consisting of PostgreSQL (database), PHP (server-side). scripting), Apache
\end{abstract}


(web server) and Front-end components consisting of JavaScript, HTML and CSS. SIRISKA web is evaluated using several parameters including website appearance, data availability, data sharing capability, map display, easy access, and CRUD facilities. Based on this evaluation, it can be concluded that the information system created can make it easier for users to exchange data and obtain information on irrigation water needs for each irrigation plot.

Keywords: Irrigation, SIRISKA, CRUD, IDS

(C) Author(s) 2021. This is an open access article under the Creative Commons Attribution-ShareAlike 4.0 International License (CC BY-SA 4.0).

\section{Pendahuluan}

Sustainable Development Goals (SDGs) merupakan suatu rencana aksi global yang disepakati oleh para pemimpin dunia, termasuk Indonesia, guna mengakhiri kemiskinan, mengurangi kesenjangan dan melindungi lingkungan. Peran penting sektor pertanian dalam program Sustainable Development Goals (SDGs) terlihat dengan ditandai adanya 17 tujuan dan 169 target yang menitikberatkan pada upaya pengentasan kemiskinan dan kelaparan. SDGs berlaku bagi seluruh negara (universal), sehingga seluruh negara tanpa kecuali negara maju memiliki kewajiban moral untuk mencapai tujuan dan target SDGs (United Nations, 2019). Dari tujuh belas tujuan tersebut, sektor pertanian termasuk dalam target kedua dari program ini yaitu "End hunger, achieve food security and improved nutrition and promote sustainable agriculture"(FAO, 2015).

Bagi Indonesia sendiri, pelaksanaan SDGs merupakan parameter terlaksananya agenda pembangunan nasional. Sejak tahun 2014 sampai dengan 2018 banyak pencapaian yang diraih Indonesia dalam mengimplementasikan SDGs baik dari sektor ekonomi, pendidikan, manajemen bencana dan iklim yang berkelanjutan. Di balik pencapaian-pencapaian tersebut, Indonesia memiliki beberapa tantangan utama dimana salah satunya yaitu data dan informasi yang tidak memadai (United Nations, 2019).

Selain itu tantangan selanjutnya dalam pengimplementasian SDGs di Indonesia yaitu perlunya inovasi untuk mendukung mobilisasi dan sumber daya domestik (United Nations, 2019). Di Jawa Tengah, prosentase alih fungsi lahan pertanian menjadi lahan industri sejak tahun 2014 s.d. 2018 adalah sekitar 69,4\% (Adiyaksa dan Djojomartono, 2020). Salah satu upaya pemerintah dalam menghadapi tantangan tersebut adalah melakukan upaya revitalisasi dan perlindungan lahan. Hal ini dilakukan dengan cara melindungi dan menjamin ketersediaan lahan, dengan menindaklanjuti UndangUndang (UU) Nomor 41 Tahun 2009 tentang Perlindungan Lahan Pertanian Pangan Berkelanjutan. Perlindungan lahan pertanian yang berkelanjutan dapat terwujud apabila parameter-parameter utama dalam pertanian tersebut dapat berjalan secara optimal dan efektif. Salah satu parameter pendukung dalam lahan pertanian yaitu irigasi pertanian.

Secara umum pengertian irigasi adalah penggunaan air pada tanah untuk keperluan penyediaan cairan yang dibutuhkan untuk pertumbuhan tanaman (Hansen dkk.,
1992). Sedangkan jaringan irigasi merupakan saluran dan bangunan yang merupakan satu kesatuan yang diperlukan untuk pengaturan air irigasi yang mencakup penyediaan, pembagian, pemberian, penggunaan dan pembuangan air irigasi. Jaringan irigasi terbagi menjadi dua yaitu saluran irigasi dan saluran pembuang (Parulian dan Yuliati, 2013). Kebutuhan air irigasi adalah jumlah volume air yang diperlukan untuk memenuhi kebutuhan evaporasi, kehilangan air, kebutuhan air untuk tanaman dengan memperhatikan jumlah air yang diberikan oleh alam melalui hujan dan kontribusi air tanah (Hansen dkk., 1992). Kehilangan air dan erosi dipengaruhi oleh faktor jenis tanah, dimana jenis tanah pada wilayah studi yaitu merupakan jenis tanah Latosol (Sudjarwadi, 1979), serta beberapa faktor lain seperti ikilm, topografi, penggunaan lahan dan tutupan lahan (Santosa dkk., 2010). Latosol merupakan jenis tanah yang relatif resisten terhadap erosi sebab mempunyai agregat tanah yang kuat (Wulandari dan Cahyono, 2020).

Manajemen irigasi bertujuan untuk mewujudkan kemanfaatan air irigasi yang menyeluruh, dan terpadu. Kemanfaatan air irigasi dapat terwujud apabila air irigasi yang dialirkan sesuai dengan kebutuhan air yang ada. Oleh karena itu dibutuhkan penghitungan dalam menentukan jumlah kebutuhan air irigasi, sehingga diharapkan dapat meningkatkan produktifitas lahan dan mencapai hasil pertanian yang optimal (Paul D. Colaizzi O'Shaughnessy dan Evans, 2014). Manajemen irigasi dilaksanakan dengan prinsip satu sistem irigasi satu kesatuan pengelolaan, dengan memperhatikan pengguna di bagian hulu, tengah dan hilir secara seimbang serta melibatkan semua pihak yang berkepentingan agar dapat dicapai pemanfaatan jaringan irigasi yang optimal (Parulian dan Yuliati, 2013).

Mengingat betapa pentingnya hal tersebut, maka peneltian ini mencoba untuk membuat suatu platform dalam bentuk sebuah website. Di dalam website tersebut, pengguna dapat melakukan tukar guna data dan mendapatkan informasi kebutuhan air irigasi untuk setiap petak lahan/daerah irigasi fungsional. Dengan didapatnya informasi tersebut, diharapkan pengguna dapat memiliki pengetahuan tentang rekomendasi yang sesuai untuk manajemen sistem irigasi (Bouman dkk., 2007).

\section{Data dan Metodologi}

\subsection{Data dan Lokasi}

Data yang digunakan dalam tulisan ini adalah sebagai berikut: 
- Daerah Irigasi, saluran irigasi dan bangunan irigasi yang ada di Kecamatan Matesih, Karangpandan dan Mojogedang, Kabupaten Karanganyar yang didapat dari DPUPKP Kabupaten Karanganyar. Data daerah irigasi memiliki format shapefile.

- Jenis Tanah Kabupaten Karanganyar yang didapat dari Dinas Pertanian Kabupaten Karanganyar. Data jenis tanah Kabupaten Karanganyar memiliki format shapefile.

- Data Klimatologi Kabupaten Karanganyar yang terdiri atas data suhu bulanan rata-rata $\left({ }^{\circ} \mathrm{C}\right)$, kelembaban bulanan rata-rata (\%), tekanan udara bulanan rata-rata (milibar), kecepatan angin ratarata (knot), hari hujan bulanan (hari). Data klimatologi Kabupaten Karanganyar didapat dari Stasiun Klimatologi Kelas I Semarang.

\subsection{Metodologi}

Tahapan pelaksanaan yang dilakukan yaitu perencanaan, pengumpulan data, analisis, desain sistem, implementasi evaluasi dan pelaporan (Gambar 2.1).

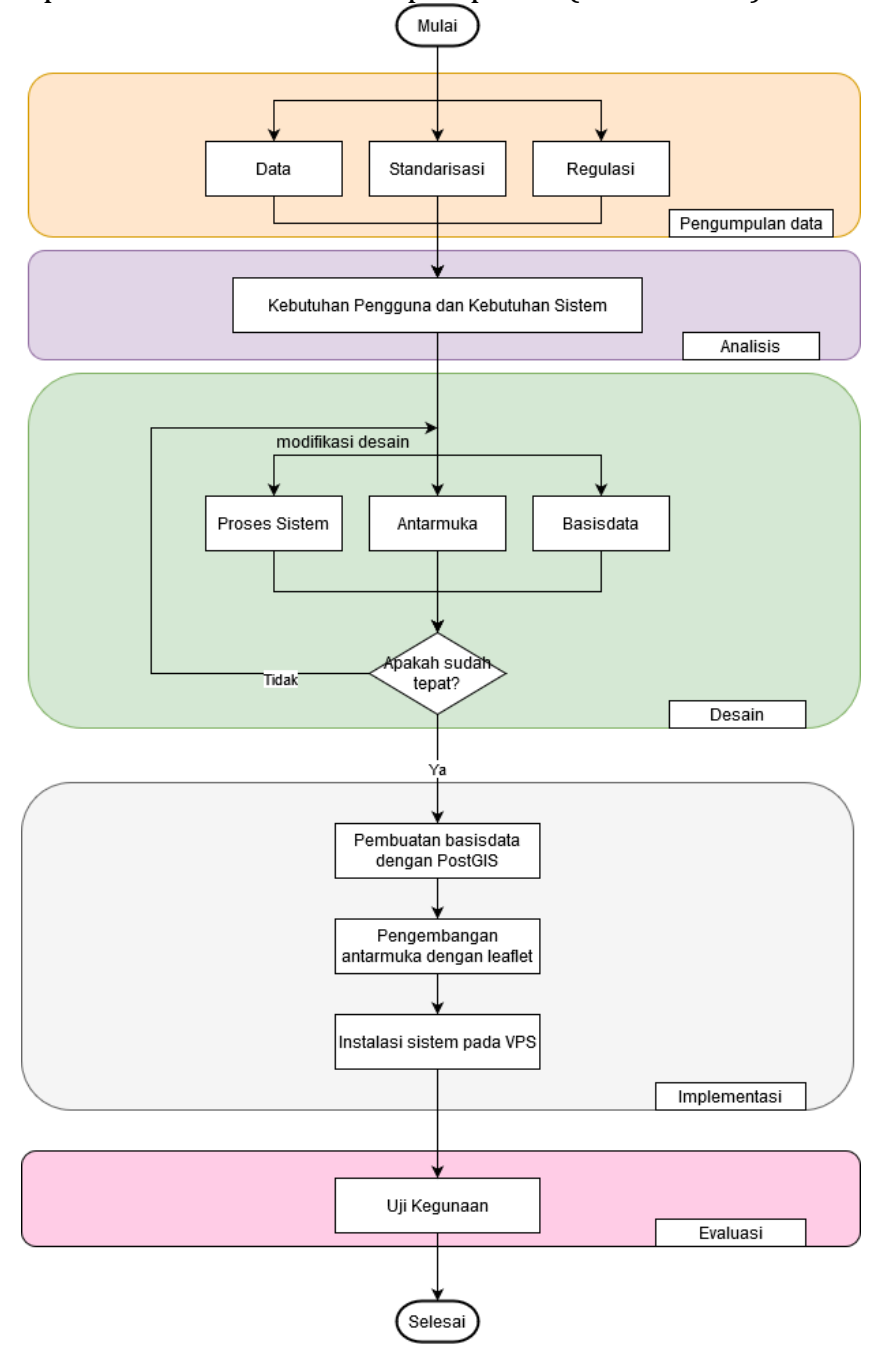

Gambar 2.1 Diagram tahapan kegiatan

\section{Pengumpulan data}

Data yang dikumpulkan dalam penelitian ini yaitu terdiri dari data (spasial dan non spasial), dokumen standarisasi dan regulasi yang berkaitan dengan manajemen irigasi pertanian. Data spasial yang dikumpulkan pada penelitian ini merupakan data spasial irigasi berformat vektor yang terdiri dari bangunan irigasi dalam bentuk titik, saluran irigasi dalam bentuk garis, dan petak irigasi dalam bentuk area.

Data tersebut diperoleh dari DPUPKP Kabupaten Karanganyar. Data non spasial yang dikumpulkan yaitu data iklim yang terdiri dari data curah hujan bulanan dengan satuan $\mathrm{mm}$, data suhu rata-rata dengan satuan derajat celcius, data kelembaban rata-rata dengan satuan persen, dan data kecepatan angin dengan satuan persen. Data iklim tersebut didapat dari Staklim BMKG Provinsi Jawa Tengah di Semarang. Data non spasial lainnya yang dikumpulkan dalam penelitian ini yaitu data porositas tanah yang didapat dari Dinas Pertanian dan Pangan Kabupaten Karanganyar.

\section{Analisis}

Analisis ini bertujuan untuk memudahkan perancangan web map yang berdasarkan kebutuhan pengguna dan kebutuhan sistem. Analisis kebutuhan pengguna yang dilakukan yaitu dengan menyebarkan kuisioner kepada responden terkait hal-hal apa saja yang dibutuhkan di dalam sebuah web map terkait manajemen irigasi. Responden tersebut merupakan orang yang ditunjuk oleh instansi terkait (Staklim BMKG Semarang, DPUPKP Kabupaten Karanganyar dan Dinas Pertanian dan Pangan Kabupaten Karanganyar) untuk mengelola data spasial khususnya data irigasi. Pertanyaan-pertanyaan yang diajukan secara garis besar yaitu terdiri dari ketersediaan data, akses data, teknologi, dan sumber daya manusia.

Analisis kebutuhan sistem perlu dilakukan sebagai upaya dalam pengembangan sistem. Analisis ini dilakukan dengan membandingkan fitur-fitur pada sistem yang sudah dikembangkan sebelumnya.

\section{Desain}

Berdasarkan analisis kebutuhan pengguna dan kebutuhan sistem didapatkan infrastruktur sistem backend yang dibuat yaitu terdiri atas tiga komponen utama yaitu web server, server-side scripting dan database. Untuk infrastruktur front end yang dibuat terdiri atas tiga komponen utama yaitu Hypertext Markup Language (HTML), Cascading Style Sheets (CSS) dan JavaScript (Gambar 2.2). 


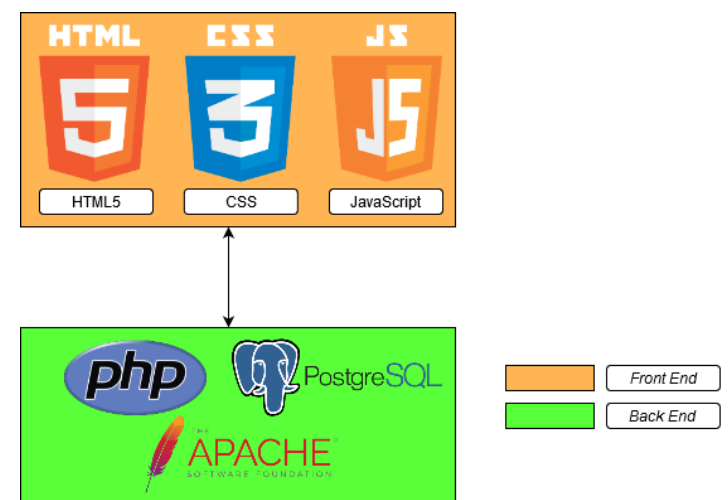

Gambar 2.2. Skema rancangan sistem

Hasil desain sistem yang dibuat terdiri dari dua yaitu diagram use case dan diagram activity. Diagram use case merupakan pemodelan untuk perilaku (behavior) sistem informasi yang dibuat. Use case mendeskripsikan sebuah interaksi antara satu atau lebih aktor dengan sistem informasi yang akan dibuat. Secara umum, use case digunakan untuk mengetahui fungsi apa saja yang ada di dalam sebuah sistem dan siapa saja yang berhak menggunakan fungsi-fungsi tersebut (Al Faruq, 2015). Diagram activity menggambarkan workflow (alur kerja) atau aktivitas dari sebuah sistem atau proses bisnis (Dumas dan Ter Hofstede, 2001; Kurnianingsih dan Santosa, 2019).

\section{Implementasi}

Pada bagian implementasi ini terdiri atas empat tahapan utama yaitu pembangunan basisdata, pengembangan antarmuka, dan intalasi pada Virtual Private Server (VPS).

\section{a) Pembangunan Basisdata}

Tahapan utama dalam pembangunan basisdata yang dilakukan yaitu perancangan basisdata konseptual, perancangan basisdata logikal dan perancangan basisdata fiskal.

Perancangan basisdata konseptual bertujuan untuk mengetahui unsur-unsur penyusun apa saja yang akan dibangun dan diteliti. Perancangan konseptual ini menggunakan cara pemodelan hubungan antar entitas atau yang sering disebut dengan Entity Relationship/E-R. Pemodelan ini digambarkan dalam bentuk diagram E-R (Gambar 2.3).

Tahapan basis data logikal berisi rangkaian hasil tahapan lanjutan dari perancangan basis data konseptual. Pada tahap ini dilakukan pemetaan proses perancangan basis data konseptual menjadi suatu model basis data yang akan digunakan dalam penelitian. Yang dilakukan dalam tahap ini penentuan atribut dari setiap entitas beserta primary key dan foreign key yang ada pada entitas tersebut (Gambar 2.4).

Pada perancangan basisdata fiskal berisi kegiatan mengimplementasikan hasil dari perancangan logikal menjadi suatu data yang tersimpan dalam suatu disk dengan menggunakan software PostgreSQL serta PostGIS. Tahapan ini bertujuan agar data disimpan dalam suatu sistem manajemen basis data. Entitas dan atribut yang sudah dirancang dan diklasifikasikan pada tahapan sebelumnya ditransformasikan ke dalam bentuk tabel.

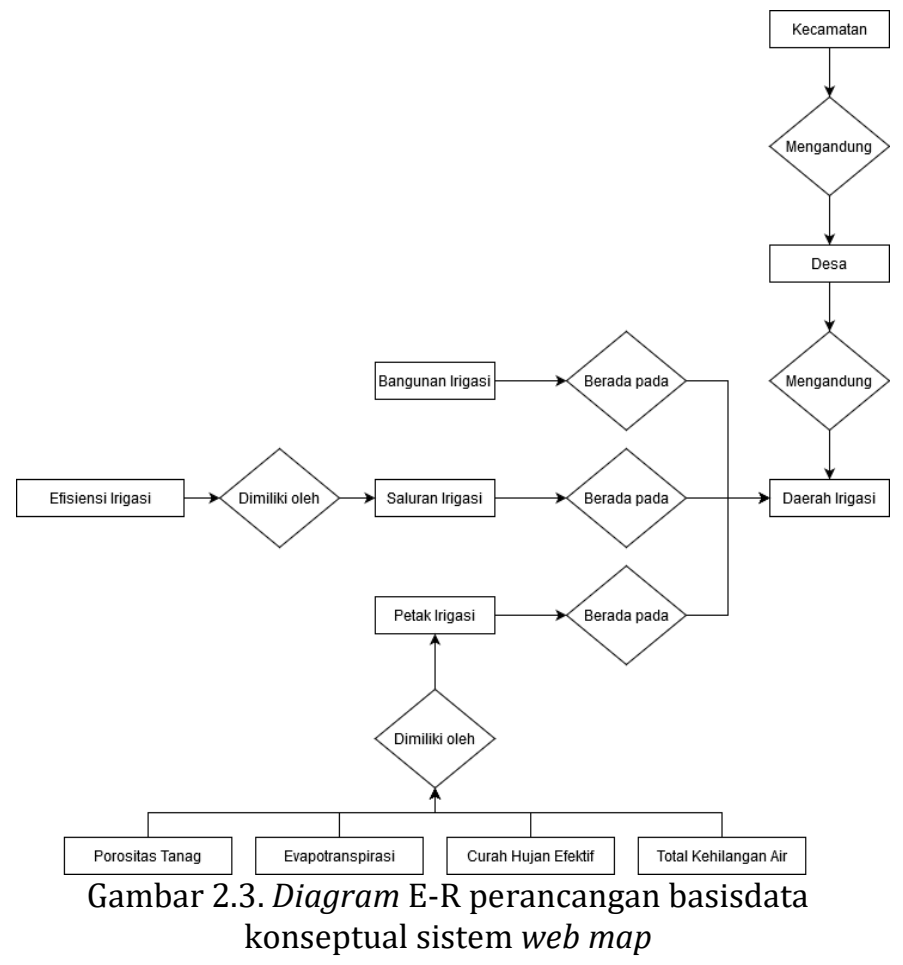

Basisdata yang dibangun menggunakan perangkat lunak opensource yaitu PostgerSQL. PostgreSQL merupakan salah satu perangkat lunak basisdata yang dapat mendukung data spasial karena di dalamnya terdapat ekstensi PostGIS. Untuk membangun sebuah basisdata, terlebih dahulu dibuat sebuah skema basisdata dan hubungan antara satu entitas dengan entitas yang lain. Pembuatan skema basisdata menggunakan PgModeller, dimana entitas yang dibangun yaitu batas administrasi (kabupaten, kecamatan dan desa), daerah irigasi, petak irigasi, saluran irigasi dan bangunan irigasi.

Skema basisdata batas administrasi memiliki hubungan entitas one to many, dengan kata lain tiap satu kabupaten memiliki beberapa kecamatan dan tiap kecamatan memiliki beberapa desa. Sedangkan untuk hubungan entitas antara desa dan daerah irigasi yaitu many to many yang mendefiniskan bahwa setiap satu desa bisa terdapat beberapa daerah irigasi dan setiap daerah irigasi bisa terletak di lebih dari satu desa.

Pada skema basisdata untuk daerah irigasi dengan saluran, bangunan dan petak irigasi memiliki hubungan one to many, dengan kata lain setiap daerah irigasi memiliki satu atau lebih saluran, bangunan dan petak irigasi. Hubungan entitas antara petak sawah dan kebutuhan air irigasi adalah one to one. Pada proses pembuatan Web ini, data vektor akan disimpan di 
database di PostgreSQL yang tujuannya agar penyimpanan data lebih rapih dan terstruktur, kemudian proses memasukan data vektor ke database akan dilakukan dengan cara import dengan menggunakan software Quantum GIS.

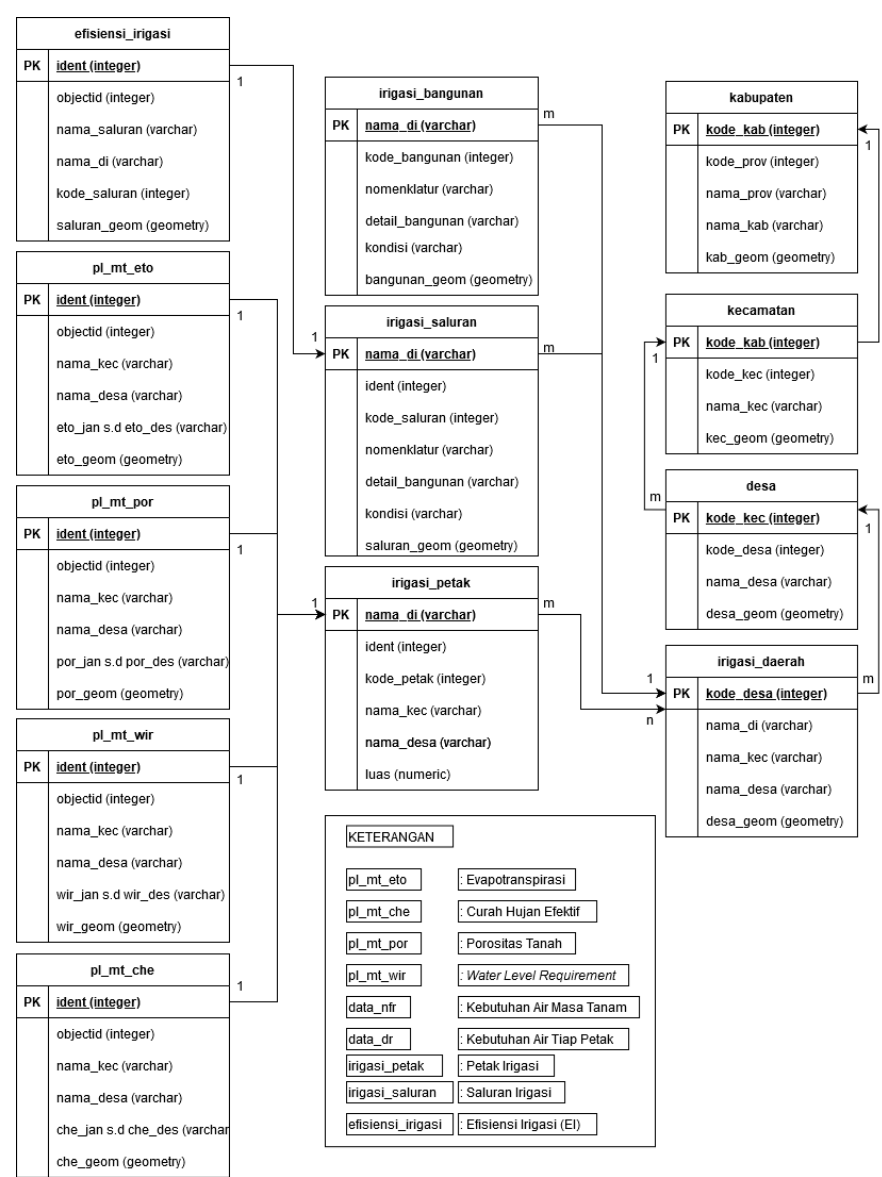

Gambar 2.4. Diagram E-R perancangan basisdata logikal sistem webmap

\section{b) Pengembangan Antarmuka Web Map}

Pengembangan antar muka web map menggunakan tiga komponen bahasa pemrograman utama yaitu HTML, CSS dan JavaScript. Web map memiliki enam menu utama yaitu Home, Data, Pembaruan Data, Tambah Data, Hapus Data, dan Unduh.

Dalam pembuatan web map dibutuhkan library yang dapat menampilkan dan memanggil data spasial baik dalam bentuk vektor maupun raster. Library yang digunakan yaitu Leaflet.js yang merupakan salah satu library yang ada di JavaScript. Pada tampilan awal antar muka web map ditampilkan basemap menggunakan metode L.tileLayer yang merupakan salah satu metode yang dimiliki Leaflet.js untuk menambahkan sebuah tile layer. Tile layer yang dimunculkan yaitu berupa tampilan rupa bumi.

Web map yang dibuat merupakan web map yang memfasilitasi akses tukar guna data irigasi, oleh karena itu data spasial irigasi merupakan data utama yang harus ditampilkan di dalam web map. Data spasial irigasi yang disimpan di dalam basisdata PostGIS dan dirubah menjadi data spasial berformat GeoJSON agar dapat ditampilkan di dalam web map.

Fasilitas Tambah Data digunakan untuk menambahkan data irigasi (bangunan irigasi, saluran irigasi dan petak irigasi) dengan cara mendigitasi langsung di atas basemap. Fungsi yang digunakan untuk menghasilkan fasilitas digitasi tersebut yaitu menggunakan fungsi L.Control.Draw. Ketika pengguna selesai melakukan digitasi, secara otomatis akan muncul formulir pengisian untuk data atribut. Fungsi yang digunakan untuk memfasilitasi hal tersebut yaitu fungsi _buildDigitiseModalBox pada Leaflet.js. Agar hasil digitasi dapat disimpan di dalam basisdata PostGIS dibutuhkan fungsi Leaflet.js lain yang dapat memfasilitasi hal tersebut yaitu fungsi addControl dan _activateFeatureSave. Data irigasi yang dapat dibuat yaitu data bangunan irigasi dalam bentuk titik, saluran irigasi dalam bentuk garis dan petak irigasi dalam bentuk area.

Fasilitas pembaruan data yang disediakan pada web map terdiri dari dua tipe pembaruan data yaitu pembaruan data spasial irigasi dengan melakukan proses editing pada feature yang sebelumnya telah dibuat dan pembaruan data atribut dengan melakukan editing atribut pada form yang disediakan. Untuk dapat melakukan proses editing data spasial irigasi pada web map digunakan fungsi e.Layers pada Leaflet.js. Sedangkan untuk melakukan proses pembaruan data atribut menggunakan fungsi bindValue pada Leaflet.js. Ketika nilai parameter kebutuhan air telah diisi dan diperbarui, secara otomatis akan terjadi proses kalkulasi yang menghasilkan nilai kebutuhan air irigasi. Proses kalkulasi secara otomatis dijalankan menggunakan fungsi PostgreSQL UPDATE dan fungsi SET yang disisipkan pada file PHP yang memfasilitasi fungsi pembaruan.

Fasilitas penghapusan data yang disediakan di dalam web map digunakan untuk menghapus data irigasi yang ada menggunakan fungsi L.control.removeLayer pada Leaflet.js. Agar tidak terjadi redundansi data, maka pada sistem web map dibuat proses penghapusan otomatis data parameter kebutuhan irigasi sesuai dengan data irigasi yang dihapus.

Fasilitas pengunduhan data yang disediakan di dalam web map terdapat dua metode pengunduhan data, yaitu pengunduhan secara langsung pada tampilan peta dan pengunduhan pada tabel pengunduhan, baik fasilitas pengunduhan pada tampilan peta maupun pada tabel pengunduhan keduanya menggunakan fungsi Leaflet.print dan fungsi onEachFeature pada Leaflet.js sehingga data yang dipilih dapat diunduh.

\section{c) Pembangunan Web map pada VPS}

VPS bisa dikatakan teknologi virtualisasi server. VPS merupakan bagian dari physical server sehingga setiap VPS bekerja bagaikan sebuah server mandiri yang secara nyata. Setiap VPS memiliki Full Root Acces, Sistem Operasi, 
dan pengaturan sendiri untuk init script, users, pemrosesan, filesystem, dan sebagainya termasuk resources server seperti CPU dan RAM yang berdiri sendiri. Hal yang membedakan antara shared hosting dengan VPS yaitu pada shared hosting, resource server digunakan secara bersama-sama dan dapat saling mempengaruhi, sedangkan untuk VPS resource server digunakan secara mandiri sehingga antara satu VPS dan VPS lain tidak akan saling mempengaruhi (Eka dkk., 2010). Tahap VPS Deployment bertujuan untuk mempersiapkan VPS yang akan digunakan untuk menempatkan platform SIG dengan melakukan instalasi dan setting pada VPS. Hal-hal yang harus dilakukan yaitu:

- Instalasi Operation System (OS) pada VPS

Operation System (OS) yang digunakan yaitu Ubuntu yang merupakan sistem operasi yang berbasis Linux dan merupakan sistem operasi open source.

- Instalasi Database pada VPS

Basisdata yang digunakan dalam penelitian ini adalah PostgreSQL 10.1. Agar basisdata dapat menyimpan data spasial maka dilakukan penambahan plugin PostGIS.

- Pembangunan web "SIRISKA"

Setelah aplikasi Web selesai dikembangkan maka Web dapat disebarkan pada VPS sehingga dapat diakses dari manapun.

\section{Uji Kegunaan}

Pada penelitian ini uji kegunaan yang dilakukan merujuk pada penelitian yang dilakukan oleh Koua (2006). Kuoa mengusulkan kriteria evaluasi kegunaan untuk aplikasi GIS berbasis web untuk evaluasi berbasis pengguna dan berbasis tugas. Kuoa berpendapat bahwa evaluasi ini bermaksud untuk menilai kemampuan aplikasi GIS untuk memenuhi kinerja dan kepuasan pengguna. Selain itu, penilaian yang dilakukan berfokus pada keefektifan, kegunaan, dan kinerja aplikasi. Hal ini penting untuk aplikasi tersebut karena uji kegunaan berdasarkan kriteria tersebut dapat memberikan pemahaman yang baik tentang masalah kegunaan pada aplikasi GIS berbasis web. Kriteria yang diuji di dalam uji kegunaan yang diusulkan oleh Koua (2006) ini terdiri atas efektivitas / kinerja pengguna, kegunaan, reaksi pengguna, konsistensi, kejelasan arsitektural visual, dan fungsionalitas. Tahapan-tahapan uji yang dilakukan dalam penelitian ini yaitu pemilihan pengguna, daftar kegiatan yang dilakukan oleh pengguna terhadap web map, dan pengisian kuisioner.

\section{Hasil dan Pembahasan}

\subsection{Hasil analisis kebutuhan}

Analisis kebutuhan yang dihasilkan ada dua yaitu hasil analisis kebutuhan pengguna dan hasil analisis kebutuhan sistem. Hasil analisis kebutuhan pengguna terdiri atas ketersediaan data, akses data, dan teknologi.
Terkait ketersediaan data, ketiga instansi memiliki tugas pokok dan fungsi yang berbeda dalam hal pengelolaan data irigasi. DPUPKP dan Dinas Pertanian merupakan instansi yang bertugas untuk mengumpulkan dan menggunakan data irigasi sedangkan untuk BMKG hanya bertugas untuk pengumpul data yang dipakai untuk kebutuhan air irigasi yaitu seperti data curah hujan. Salah satu tugas utama dari DPUPKP khususnya Sumber Daya Air yaitu mengumpulkan data debit air yang ada di saluran irigasi. Data debit air dapat digunakan untuk menghitung nilai efisiensi irigasi. Selain data spasial, sistem koordinat juga penting dalam penentuan posisi suatu data. Dalam penerapannnya, institusi yang menjadi responden dalam penelitian ini menggunakan Sistem Koordinat Geografis.

Terkait akses data, ketiga instansi belum menerapkan atau mengadopsi standar pada data spasial irigasi. Di antara ketiga instansi tersebut hanya BMKG satu-satunya instansi yang memanfaatkan GIS service yaitu dalam bentuk feature service. Dalam pelaksanaan tugas dan fungsinya koneksi jaringan yang digunakan oleh ketiga instansi yaitu jaringan internet dimana arsitektur jaringan yang dikembangkan yaitu network gateway dan central server. Kendala utama yang dihadapai oleh ketiga instansi yaitu kurangnya informasi dan teknologi komunikasi pada instansi-instansi tersebut.

Terkait teknologi, aspek yang dilihat yaitu kesiapan dari instansi tersebut terhadap adanya teknologi web map dilihat dari teknologi hardware dan software yang ada. Sistem operasi yang digunakan oleh ketiga instansi sudah mendukung untuk diadakannya mekanisme tukar guna data menggunakan sistem web map. Dengan terhubungnya setiap Personal Computer (PC) pada jaringan internet semakin mempertegas bahwa mekanisme tukar guna data spasial menggunakan sistem web map sangat dibutuhkan. Dengan adanya web map yang dapat melakukan proses penambahan data spasial berupa digitasi langsung, pengguna dapat melakukan proses penambahan data tanpa harus menggunakan perangkat lunak SIG.

Setiap instansi yang memiliki sistem informasi akan diberikan fasilitas server oleh Kementerian Komunikasi dan Informasi, sehingga memudahkan dalam pengembangan web map. Selain server, basisdata juga merupakan hal yang penting dalam pembuatan web map. DPUPKP dan Dinas Pertanian dan Pangan Kabupaten Karanganyar menggunakan MySQL sebagai Sistem Manajemen Basisdata, sedangkan BMKG menggunakan Oracle untuk Sistem Manajemen Basisdata pada instansi tersebut.

\subsection{Hasil desain sistem \\ Use case diagram}

Dalam pembuatan use case diagram website SIRISKA ini terdapat 4 tahapan utama yaitu pendefinisian aktor yang terlibat, pendefinisian use case, pembuatan skenario, dan penggambaran use case diagram. Pendefinisian aktor yang terlibat disajikan pada Tabel 3.1 
Tabel 3. 1 Pendefinisian aktor dalam use case diagram Aktor Deskripsi

Pengguna

Pengguna adalah penyuluh pertanian,
mantra tani, petani dan masyarakat
yang memiliki hak akses untuk
melihat, mengedit dan menganalisis
data terkait manajemen irigasi
Administrator merupakan seseorang
yang diberi tanggung jawab dalam
mengelola basisdata.

Use case dijabarkan berdasarkan dari interaksi yang ada di dalam sistem. Penjabaran tersebut disajikan dalam Tabel 3.2.

Tabel 3. 2 Pendefinisian use case

\begin{tabular}{llll}
\hline & \multicolumn{2}{c}{ Use Case } & \multicolumn{3}{c}{ Deskripsi } \\
\hline $\mathbf{1}$ & Registrasi & $\begin{array}{l}\text { Proses dimana akun pengguna yang } \\
\text { baru didaftarkan }\end{array}$ \\
\hline $\mathbf{2}$ & Login & $\begin{array}{l}\text { Proses login yang dilakukan oleh } \\
\text { pengguna yang telah terdaftar }\end{array}$ \\
\hline $\mathbf{3}$ & Input & $\begin{array}{l}\text { Proses memasukan informasi berupa } \\
\text { data yang dibutuhkan untuk } \\
\text { manajemen irigasi }\end{array}$ \\
\hline $\mathbf{4}$ & Validasi data & $\begin{array}{l}\text { Proses cek kesesuaian informasi akun } \\
\text { pengguna pada saat login }\end{array}$ \\
\hline $\mathbf{5}$ & Vangguna & $\begin{array}{l}\text { Proses cek kesesuaian informasi baik } \\
\text { input, edit dan } \\
\text { analisis }\end{array}$ & $\begin{array}{l}\text { yang dimasukkan, di-edit maupun } \\
\text { dianalisis oleh pengguna }\end{array}$ \\
\hline $\mathbf{6}$ & Mengelola & $\begin{array}{l}\text { Proses pengelolaan basis data } \\
\text { basisdata }\end{array}$ & (tambah, cari, edit, hapus) \\
\hline $\mathbf{7}$ & Logout & $\begin{array}{l}\text { Proses untuk mengakhiri penggunaan } \\
\text { sistem. }\end{array}$ \\
\hline
\end{tabular}

Penggambaran use case diagram dibuat berdasarkan keempat skenario use case yang telah dijelaskan sebelumnya. Gambar use case diagram disajikan pada gambar 3.1.

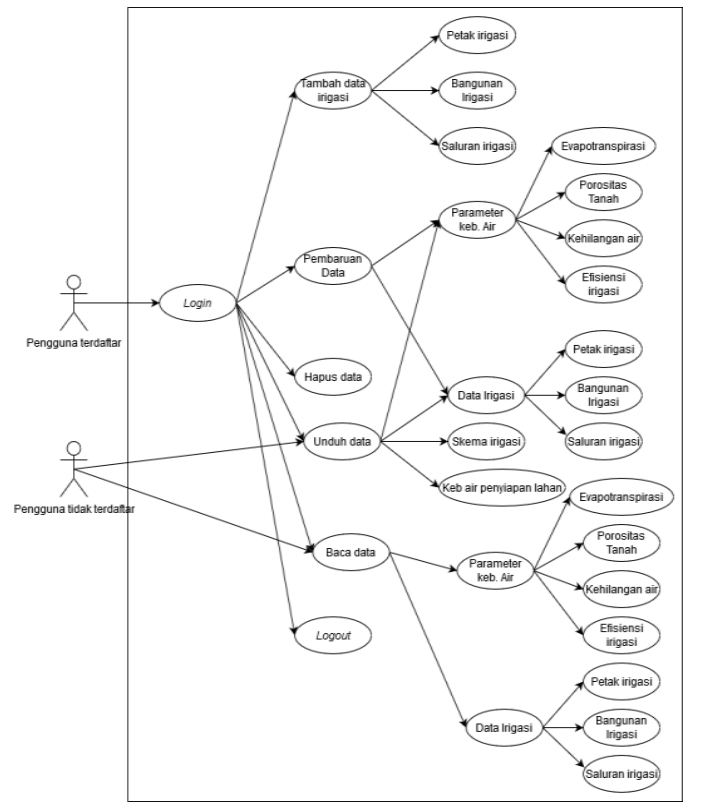

Gambar 3.1. Use case diagram pada website SIRISKA

\section{Activity diagram}

Activity diagram merupakan sebuah penggambaran aktivitas antara pengguna dan sistem dari awal sampai akhir. Gambar 3.2 menyajikan activity diagram pada website SIRISKA.
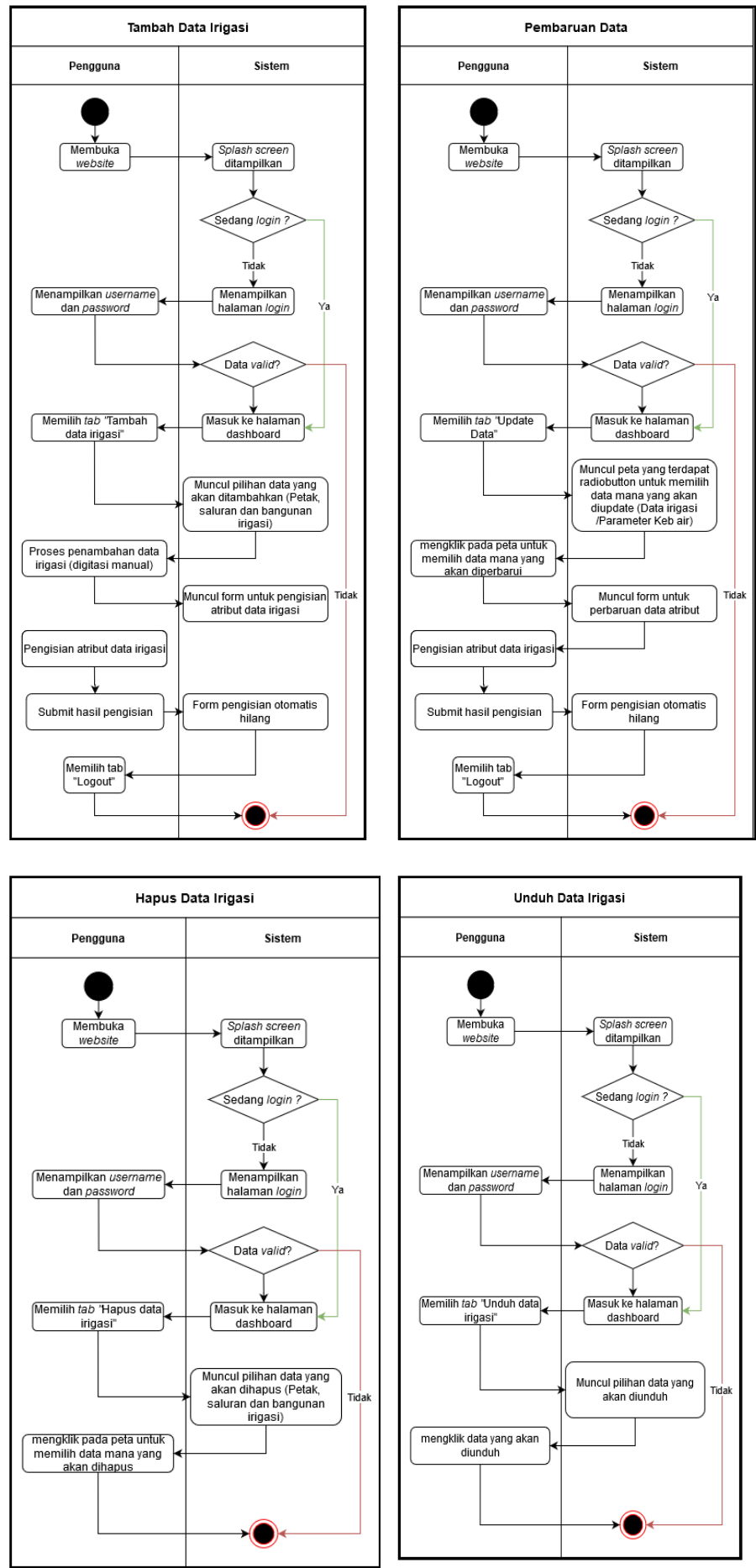

Gambar 3.2. Activity diagram pada website SIRISKA

3.3. Hasil Pengembangan Antarmuka

\section{Halaman muka}

Halaman muka digunakan untuk menampilkan informasi mengenai aplikasi web SIRISKA. Tampilan 
utama secara default sebagai data basemap yaitu data OpenStreetMap. Selain itu, pengguna dapat memilih basemap lain yang disediakan dalam web SIRISKA yaitu di antaranya, Google Satellite, Google Hybrid, Google Street dan Google Terrain. Tanpa melakukan sign in pengguna dapat melihat data batas administrasi dan data irigasi yang ada. Batas administrasi yang disediakan yaitu batas administrasi kabupaten, kecamatan dan desa. Untuk data irigasi yang disediakan yaitu di antaranya data daerah irigasi, petak irigasi, bangunan irigasi dan saluran irigasi.

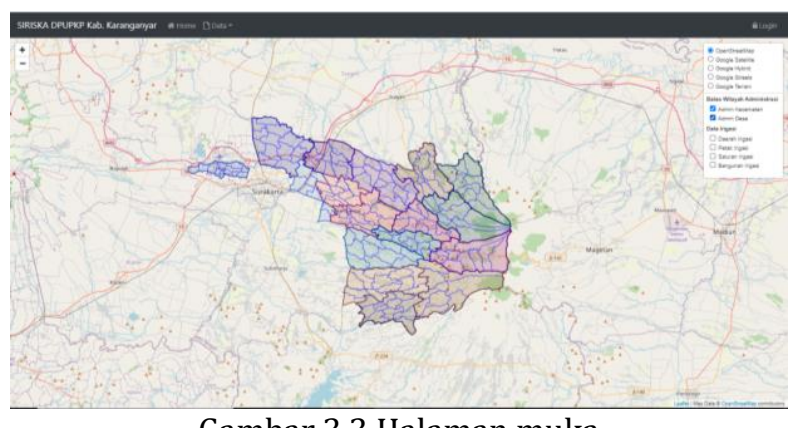

Gambar 3.3 Halaman muka

Data daerah irigasi merupakan data petak irigasi yang dikumpulkan berdasarkan nama daerah irigasinya. Tampilan geometri daerah irigasi yaitu berupa area. Dengan memanfaatkan fitur download yang ada pada platform leaflet.js kita dapat mengunduh skema irigasi yang ada pada data irigasi yang ada di basisdata PostGIS yang telah disimpan sebelumnya. Hasil dari pengunduhan skema irigasi dapat dilihat pada Gambar 3.4.

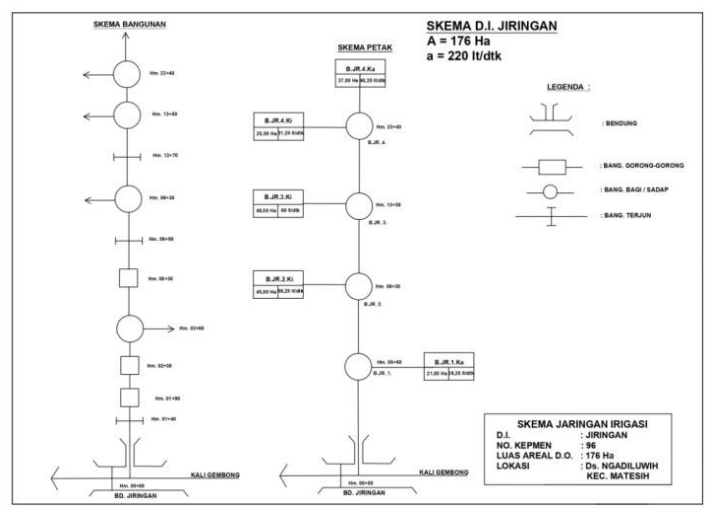

Gambar 3.4 Hasil pengunduhan skema irigasi dari

Petak irigasi merupakan petak lahan (baik sawah maupun perkebunan lainnya) yang mendapatkan aliran irigasi dari saluran irigasi, baik sekunder, tersier maupun kuarter. Data petak irigasi yang ditampilkan pada web SIRISKA yaitu kode petak irigasi, nama daerah irigasi, Desa, Kecamatan, luas petak irigasi, dan pemilik (Gambar 3.5).

Saluran irigasi merupakan merupakan sarana penghubung antara sumber air dan petak tanah pertanian atau persawahan. Saluran irigasi berdasarkan cabang terdiri atas empat klasifikasi yaitu saluran primer, saluran sekunder, saluran tersier dan saluran kuarter. Total data saluran irigasi yang ada pada web SIRISKA berjumlah 82 saluran irigasi. Data saluran irigasi yang ditampilkan pada web SIRISKA yaitu diantaranya kode saluran, nomenklatur saluran, detail saluran, kondisi saluran, daerah irigasi, desa dan kecamatan. Tipe geometri saluran irigasi yang ditampilkan yaitu berupa line (garis). Contoh tampilan data saluran irigasi ditunjukkan pada Gambar 3.6.

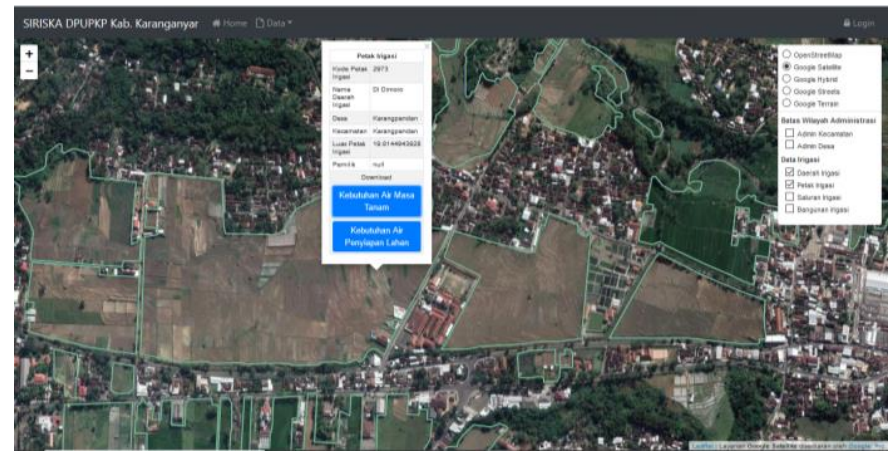

Gambar 3.5 Tampilan data petak irigasi

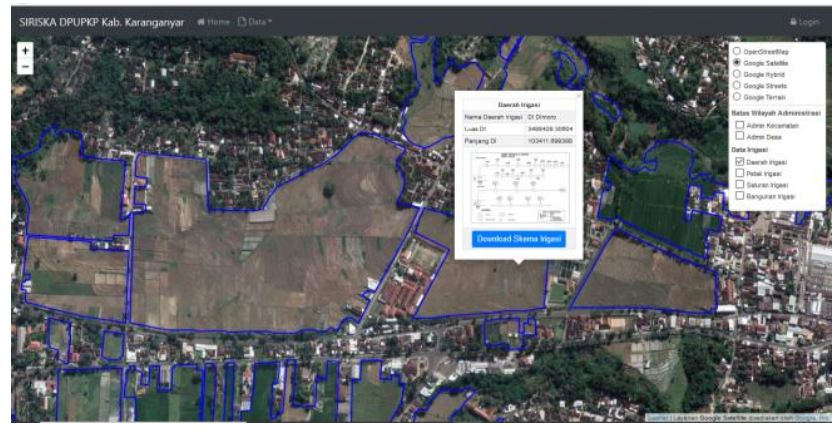

Gambar 3.6 Tampilan data daerah irigasi

\section{Fasilitas login}

Fasilitas login digunakan untuk membedakan pengguna berdasarkan jenis kebutuhannya. Web map SIRISKA ini terdapat dua jenis pengguna yaitu pengguna terdaftar, dan pengguna tidak terdaftar. Untuk pengguna tidak terdaftar, layanan yang dapat digunakan yaitu layanan yang ada pada tab control yang berupa penampilan data batas admin, data irigasi dan download skema irigasi. Untuk pengguna terdaftar dapat menggunakan semua layanan yang ada pada web map SIRISKA. Layanan tersebut di antaranya layanan pembaruan data, penambahan data, penghapusan data, dan pengunduhan data. Salah satu kelebihan yang dapat dilakukan oleh admin yaitu admin dapat menonaktifkan pengguna yang telah terdaftar. Ketika login, admin memfilter pengguna bukan hanya dari username dan password saja, tetapi dengan penambahan status pengguna.

Apabila username dan password yang dimasukkan benar dan admin memberi keterangan status yang aktif pada pengguna, maka pengguna dapat login dan menggunakan beberapa fasilitas yang tidak ada ketika pengguna tersebut belum melakukan login.

Fasilitas yang ada ketika pengguna login merupakan fasilitas yang digunakan untuk melakukan pembaruan, penambahan, dan penghapusan data seperti terlihat pada 
Gambar 3.7. Fasilitas ini diperuntukkan kepada petugas instansi pemerintah seperti penyuluh pertanian ataupun mantri tani, yang memang memiliki tugas pokok terkait pendataan parameter-parameter kebutuhan air irigasi untuk pertanian.

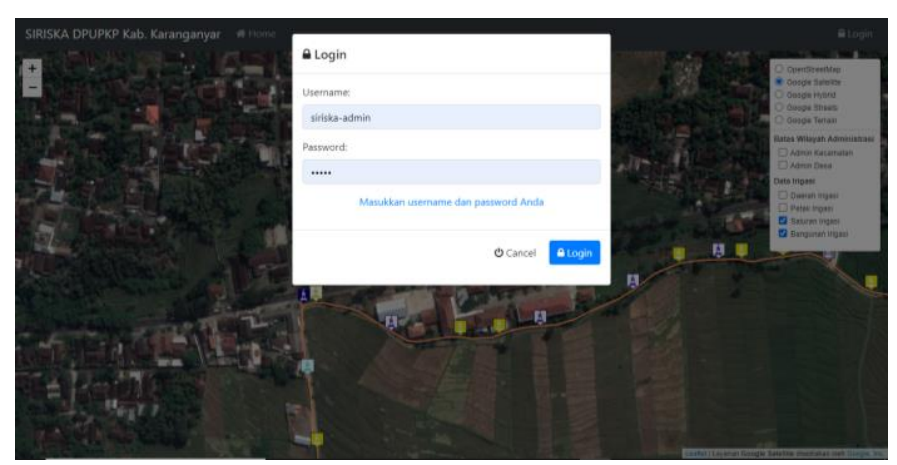

Gambar 3.4 Tampilan login

\section{Fasilitas pembacaan data}

Fasilitas pembacaan data dilakukan dengan dua cara yaitu secara spasial langsung pada map dan secara tabular (Gambar 3.8). Hal ini bertujuan untuk memudahkan pengguna dalam melihat data secara keseluruhan. Data yang dapat dilihat secara tabular yaitu data irigasi (daerah irigasi, petak irigasi, saluran irigasi, dan bangunan irigasi) dan parameter kebutuhan irigasi (evapotranspirasi, efisiensi irigasi, curah hujan efektif, porositas tanah, dan total kehilangan air).

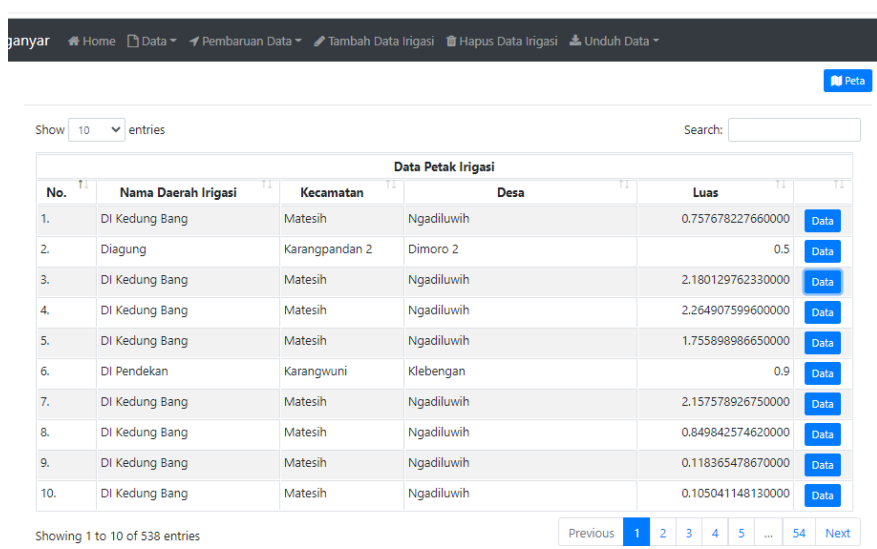

Gambar 3.5 Tampilan data tabular irigasi

Tabel data petak irigasi memiliki hubungan one to one dengan empat parameter kebutuhan air irigasi yaitu evapotranspirasi, curah hujan efektif, porositas tanah, dan total kehilangan air pada permukaan tanah. Sedangkan tabel data saluran irigasi memiliki hubungan one to one dengan data efisiensi irigasi. Oleh karena itu, ketika pengguna meng-klik tombol data pada salah satu petak irigasi, maka dapat muncul empat parameter kebutuhan yang menyangkut petak irigasi yaitu evapotranspirasi, curah hujan efektif, porositas tanah, dan total kehilangan air pada permukaan tanah seperti pada Gambar 3.9. Fasilitas ini bertujuan untuk memudahkan pengguna untuk melakukan crosscheck terhadap data yang telah ditambahkan ataupun diperbarui secara cepat tanpa harus membuka basisdata utama PostGIS.

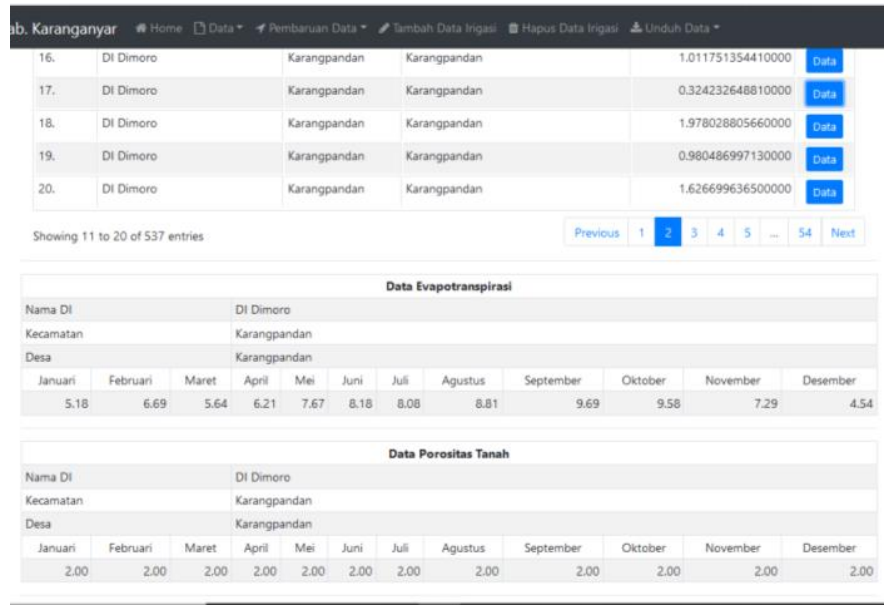

Gambar 3.6 Tampilan ketika tombol "data" diklik

\section{Fasilitas penambahan data}

Pada fasilitas penambahan data, pengguna dapat membuat data petak irigasi (polygon), saluran irigasi (line), dan bangunan irigasi (point) seperti pada Gambar 3.10. Pengguna dapat melakukan digitasi manual untuk membuat data irigasi tersebut. Ketika pengguna selesai melakukan digitasi, maka akan muncul form untuk pengisian data non-spasial/atribut pada data yang telah didigitasi.

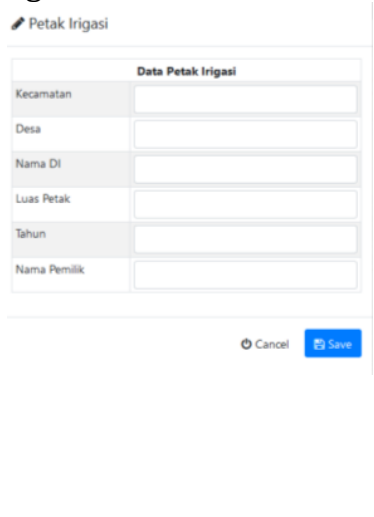

(a)

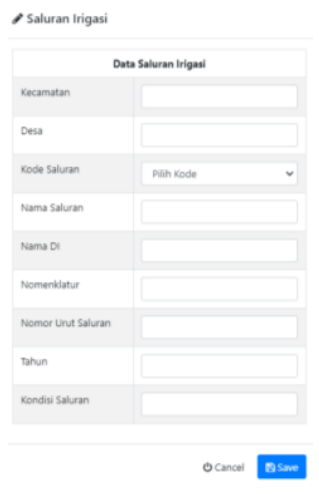

(b)

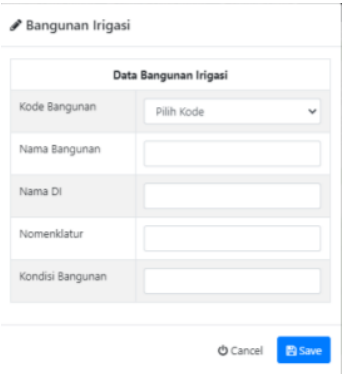

(c)

Gambar 3.7 Form untuk pengisian atribut data irigasi (a) Petak Irigasi, (b) Saluran Irigasi dan (c) Bangunan Irigasi 
Ketika petak irigasi dibuat, maka secara otomatis pada tabel parameter kebutuhan air irigasi (evapotranspirasi, kehilangan air, curah hujan efektif dan porositas tanah) dalam basisdata dapat muncul ide baru yang unik dan dengan nilai masing-masing parameter yang masih kosong. Demikian pula, ketika saluran irigasi dibuat maka parameter kebutuhan air sisanya yaitu efisiensi irigasi secara otomatis dapat terbuat juga. Dengan adanya sistem tersebut, satu parameter kebutuhan air irigasi pasti memiliki satu data irigasi.

\section{Fasilitas pembaruan data}

Parameter kebutuhan air digunakan untuk proses kalkulasi secara otomatis nilai dari kebutuhan air irigasi, baik pada saat penyiapan lahan maupun pada saat masa tanam. Kebutuhan air pada saat penyiapan lahan parameter yang dibutuhkan yaitu evapotranspirasi, porositas, total kehilangan air, jangka waktu penyiapan lahan, tinggi penjenuhan, konstanta kebutuhan air, dan luas lahan. Kebutuhan air pada saat masa tanam parameter yang dibutuhkan yaitu evapotranspirasi, curah hujan efektif, porositas, pergantian lapisan air, efisiensi irigasi, dan luas lahan.

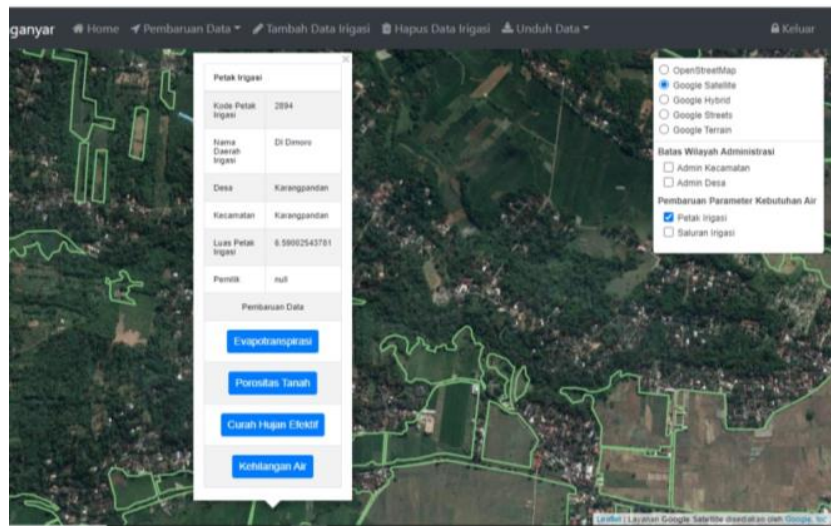

Gambar 3.8 Tampilan pop-up untuk memilih data yang diperbarui

Pembaruan, dilakukan dengan meng-klik salah satu poligon petak irigasi yang ada. Setelah itu, muncul keterangan petak irigasi dan parameter kebutuhan air irigasi sesuai dengan hal yang ingin diperbarui. Pilihan data parameter kebutuhan air irigasi tersebut yaitu evapotranspirasi, porositas tanah, curah hujan efektif, dan kehilangan air seperti pada Gambar 3.11.

Setelah pengguna memilih salah satu parameter kebutuhan air irigasi yang diperbarui, mucul form pengisian seperti pada Gambar 3.12. Form tersebut diisi berdasarkan periode bulan dari bulan Januari sampai dengan Desember. Tampilan form untuk ketiga parameter sisanya, yaitu Curah Hujan Efektif, Porositas Tanah dan Kehilangan Air menggunakan cara yang sama. Setelah semua parameter kebutuhan air irigasi diisi ataupun diperbarui, secara otomatis sistem mengkalkulasi data tersebut menghasilkan nilai kebutuhan air irigasi. Nilai kebutuhan air irigasi tersebut dibagi menjadi dua yaitu nilai kebutuhan air irigasi saat penyiapan lahan dan kebutuhan air irigasi saat masa tanam.

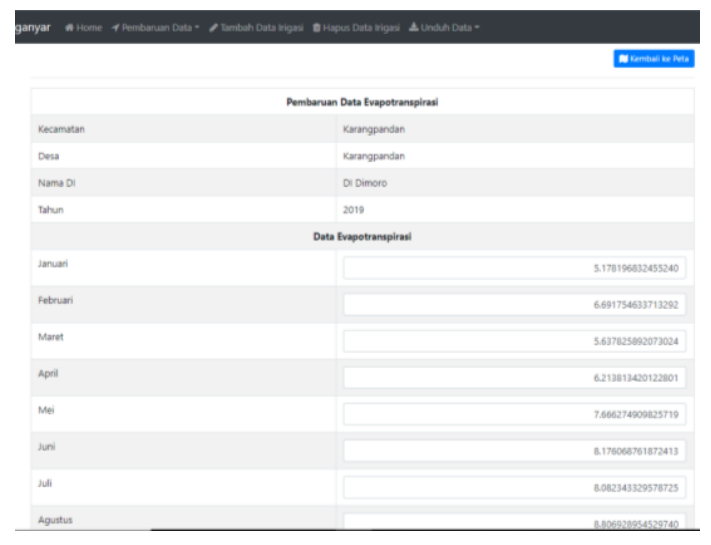

Gambar 3.9 Form pembaruan data irigasi

\section{Fasilitas penghapusan data}

Fasilitas penghapusan data digunakan untuk menghapus data irigasi (petak irigasi, saluran irigasi dan bangunan irigasi). Fasilitas penghapusan data ini hanya dapat dilakukan oleh pengguna terdaftar yang telah melakukan login terlebih dahulu, sehingga apabila pengguna belum melakukan login, pilihan "hapus data" tidak akan muncul pada antarmuka website SIRISKA. Ketika pengguna menghapus data petak irigasi maka data parameter kebutuhan air irigasi seperti evapotranspirasi, curah hujan efektif, porositas tanah dan kehilangan air otomatis terhapus. Begitupula ketika pengguna menghapus data saluran air irigasi maka data efisiensi irigasi yang juga merupakan data parameter kebutuhan air irigasi dapat terhapus. Hal ini dikarenakan ada keterkaitan antara data petak irigasi dan saluran irigasi dengan kelima data parameter kebutuhan air tersebut. Sedangkan untuk bangunan irigasi, ketika bangunan irigasi dihapus, tidak ada parameter kebutuhan irigasi yang secara otomatis terhapus.

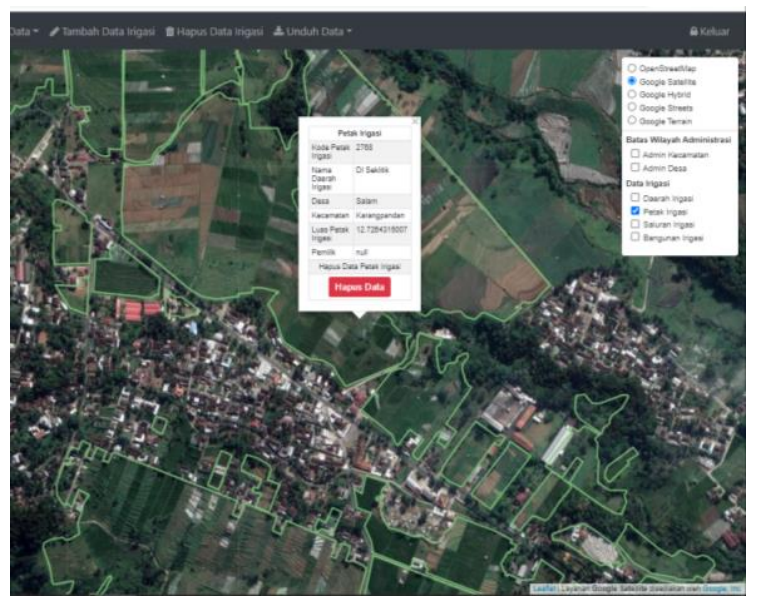

Gambar 3.10 Tampilan popup untuk melakukan penghapusan data 


\section{Fasilitas pengunduhan data}

Fasilitas pengunduhan data (Gambar 3.14) digunakan untuk mengunduh data petak irigasi, data parameter kebutuhan air, data skema irigasi dan data nilai kebutuhan air irigasi. Data petak irigasi dan parameter kebutuhan air yang diunduh berupa data dengan format GeoJSON. Pengguna dapat melakukan pengunduhan data dengan dua cara yaitu dapat mengunduh secara keseluruhan dan juga dapat mengunduh data untuk tiap petaknya seperti yang terlihat pada Gambar 3.15.

Data skema irigasi yang diunduh berupa data gambar berformat ${ }^{*}$.jpeg, sedangkan data nilai kebutuhan air irigasi yang diunduh berupa dokumen berformat *.pdf. Data nilai kebutuhan air yang didapat berupa nilai kebutuhan air irigasi tiap bulan dari Bulan Januari sampai dengan Bulan Desember.

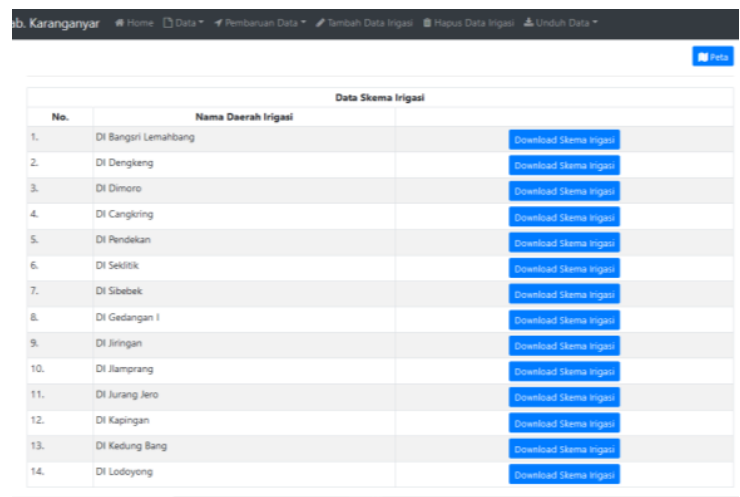

Gambar 3.11 Fasilitas pengunduhan skema irigasi

Hasil pengunduhan data parameter kebutuhan air irigasi yaitu memiliki format GeoJSON. Pemilihan format GeoJSON sebagai format yang digunakan sebagai hasil dari proses pengunduhan data yaitu karena GeoJSON menyimpan data dalam bentuk array sehingga transfer data menjadi lebih mudah. Geojson memiliki konsep penguraian data yang mudah dan eksekusi data yang lebih cepat. Selain itu GeoJSON dapat dibuka di berbagai perangkat lunak GIS seperti Quantum GIS dan ArcGIS Pro.

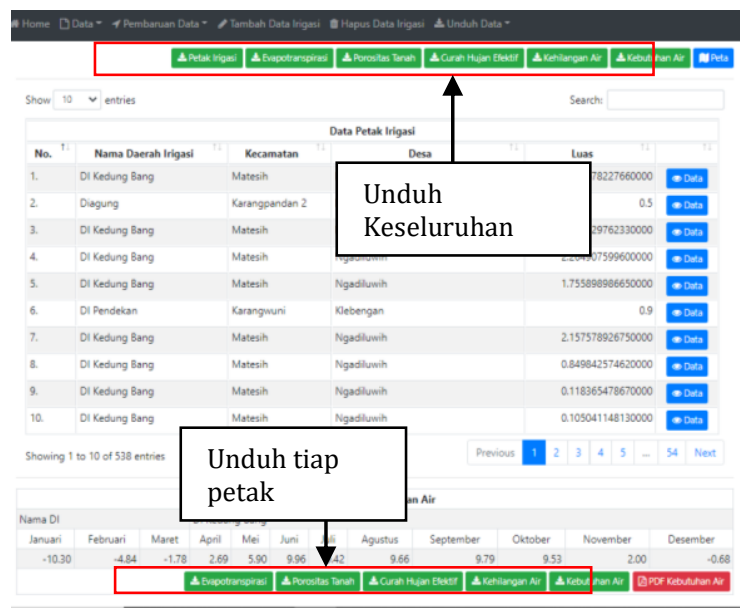

Gambar 3.12 Tampilan fasilitas unduh data

\section{Uji Kegunaan}

Uji kegunaan pada web map bertujuan untuk menilai apakah sistem yang dirancang sesuai dengan yang diharapkan. Parameter-parameter yang digunakan untuk menilai yaitu, efektivitas, kegunaan, konsistensi, kejelasan arsitektural dan visual, dan kemampuan data sharing.

\section{a. Efektifitas}

Efektivitas berkaitan dengan aspek fungsionalitas dari aplikasi web map yang dibuat. Aspek pertama diuji terkait evaluasi efektivitas dalam web map ini terkait perbandingan waktu dihabiskan penggunaan aplikasi web map SIRISKA dan aplikasi perangkat lunak SIG Desktop. Aspek kedua yang diuji yaitu mengenai tingkat kebutuhan dari fasilitas-fasilitas yang disediakan di dalam web map. Hasilnya disajikan pada Gambar 3.16.

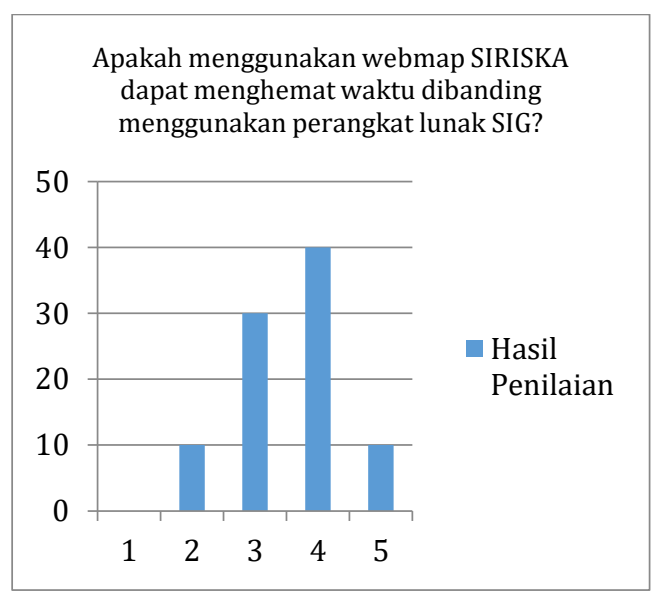

(a)

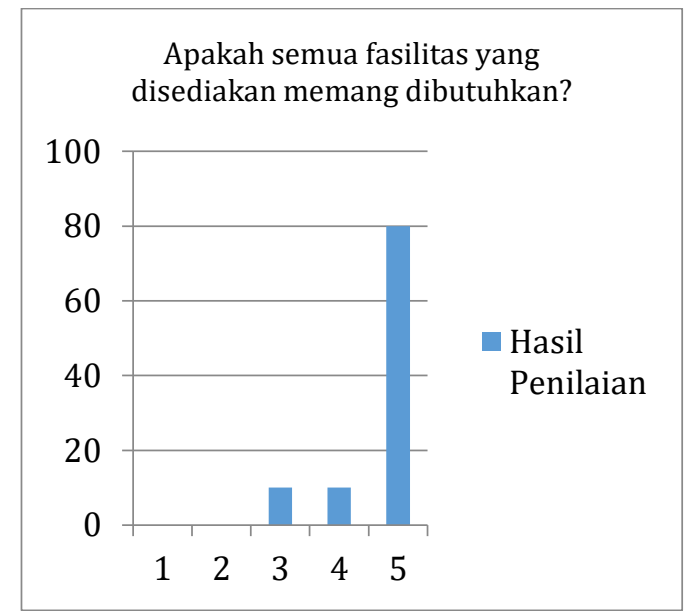

(b)

Gambar 3.13 (a) Aspek pertama dan (b) aspek kedua yang diuji terkait evaluasi efektifitas web map SIRISKA

b. Kebergunaan

Kebergunaan berkaitan dengan harapan dan permintaan pengguna saat menggunakan aplikasi web map. Evaluasi kebergunaan ini terkait dengan kemampuan 
pengguna untuk dapat memahami dan menafsirkan hasil web map. Aspek pertama yang diuji yaitu untuk melihat tingkat kemudahan dalam penggunaan web map. Aspek kedua yang diuji yaitu untuk melihat apakah web map dibuat dapat mendukung tujuan dan pekerjaan pengguna. Aspek terakhir yang diuji dalam evaluasi kebergunaan ini untuk melihat apakah langkah-langkah dalam penggunaan fasilitas pada web map mudah untuk dipahami dan diingat oleh pengguna. Hasilnya disajikan pada Gambar 3.17.

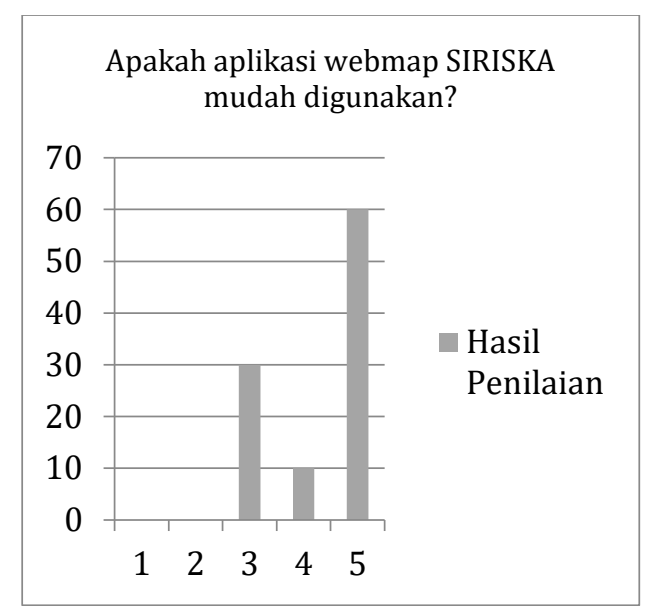

Gambar 3.14 Aspek pertama diuji dalam uji kebergunaan

Pada hasil pengujian aspek pertama untuk uji kebergunaan, dapat dilihat bahwa 60 persen dari total pengguna setuju bahwa web map mudah digunakan. Hal ini dikarenakan web map SIRISKA minim akan simbolsimbol dan fungsi-fungsi yang dapat menyulitkan pengguna. Selain itu dengan menggunakan HTML5, tampilan webmap dapat secara responsive digunakan oleh pengguna sehingga web map dapat dibuka dan digunakan di berbagai perangkat baik PC maupun mobile. Hasilnya disajikan pada Gambar 3.18.

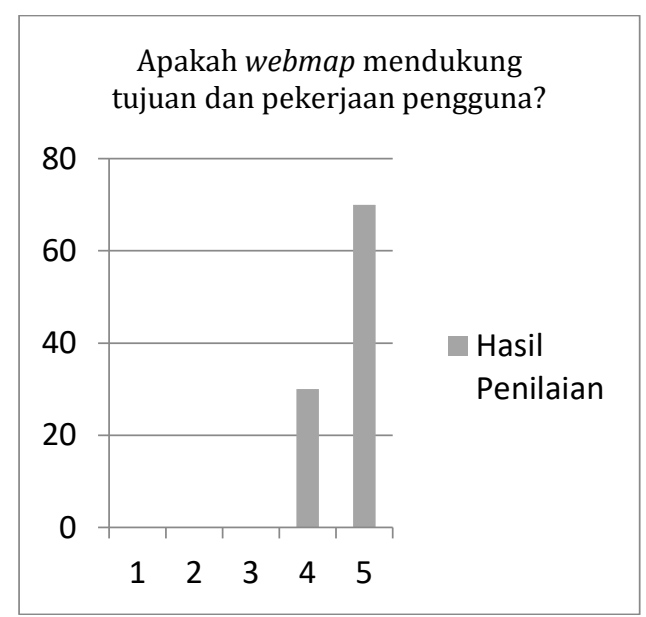

(a)

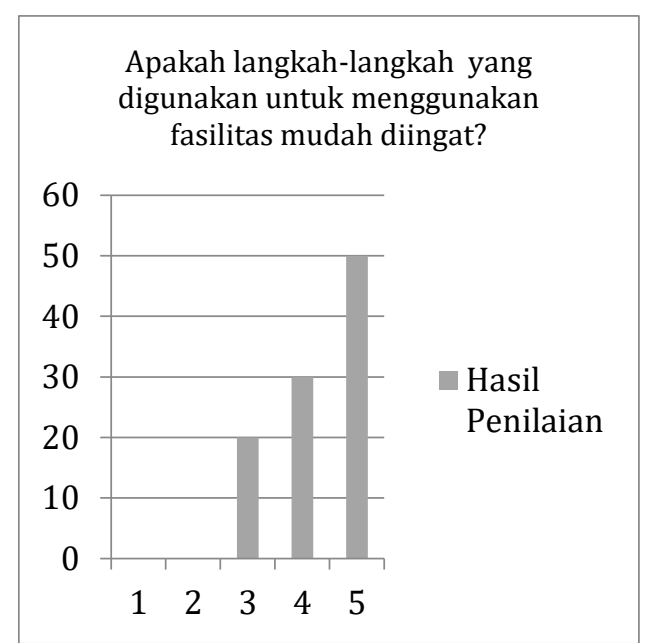

(b)

Gambar 3.15 (a) aspek kedua dan (b) aspek ketiga yang diuji dalam uji kebergunaan

Pada aspek pengujian kedua dapat dilihat bahwa 70 persen dari total pengguna setuju bahwa web map mendukung tujuan dan pekerjaan pengguna. Fasilitas CRUD pada web map memudahkan pengguna dalam menggunakan data irigasi secara maksimal. Selain itu, ketika pengguna melakukan penambahan ataupun pembaruan data irigasi (bangunan irigasi, saluran irigasi dan petak irigasi), di dalam form pengguna dapat mengisi kondisi dari data irigasi tersebut (misalnya: kondisi bangunan irigasi sudah tidak layak). Hasil dari pengisian tersebut dapat dilihat pengguna lain dalam hal ini pengambil kebijakan sehingga secara tidak langsung dapat memonitor keadaan irigasi yang ada. Pada aspek pengujian ketiga dapat dilihat bahwa 50 persen setuju bahwa langkah-langkah untuk menggunakan fasilitas yang ada di web map mudah dipahami. Hal ini dikarenakan kerja sistem untuk tiap-tiap fasilitas dibuat seragam sehingga memudahkan pengguna ketika ingin menggunakan fasilitas berbeda.

\section{c. Konsistensi}

Uji konsistensi bertujuan untuk melihat apakah sistem memiliki mekanisme kerja yang konsisten dan seragam. Hal ini berkaitan kemudahan pengguna dalam memahami tampilan webmap. Semakin konsisten dan seragam mekanisme kerja sistem di dalam webmap maka akan semakin mudah untuk dipahami. Oleh karena itu aspek yang diuji pada uji konsistensi ini yaitu untuk melihat apakah tampilan webmap tetap konsisten saat menavigasi ke halaman yang berbeda. 


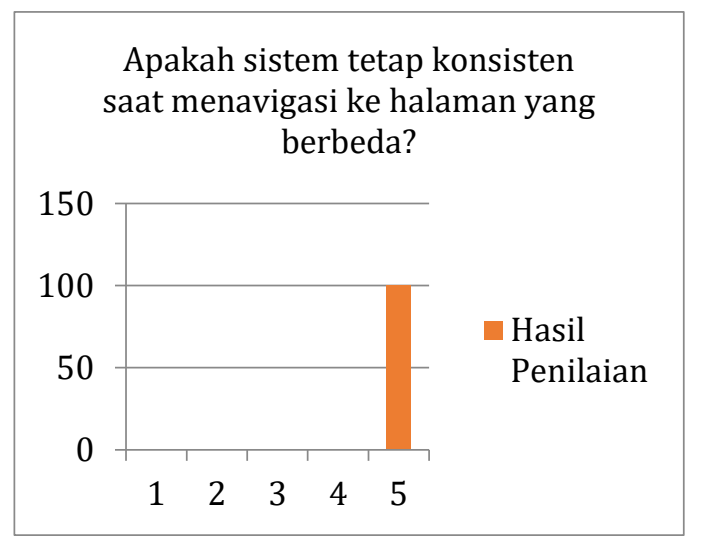

Gambar 3.16 Aspek yang diuji pada uji konsistensi

Pada aspek pengujian yang ditunjukkan pada Gambar 3.9 dapat dilihat bahwa 100 persen dari total pengguna setuju bahwa sistem tetap konsisten saat menavigasi ke halaman yang berbeda. Konsistensi dalam perpindahan halaman merupakan salah satu yang dijadikan konsen oleh penulis, hal ini dikarenakan semakin konsisten dan seragam halaman, fitur dan fasilitas yang ada maka akan semakin mudah dipahami oleh pengguna.

\section{d. Kejelasan arsitektural dan visual}

Parameter tampilan merupakan salah satu parameter penting apakah webmap yang dibuat sudah mewakili kebutuhan pengguna. Ada tiga aspek utama dalam menguji kejelasan arsitektur dan visual dari webmap yang ada. Aspek pertama yaitu untuk melihat apakah setiap halaman memiliki informasi terorganisir yang sama. Aspek yang kedua yaitu untuk melihat efektifitas simbol yang ditampilkan pada webmap. Aspek ketiga yaitu untuk melihat apakah sistem dirancang untuk semua tingkatan pengguna.

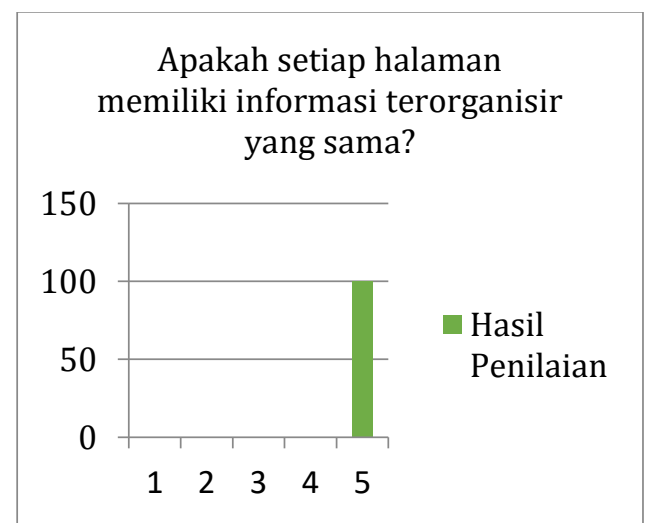

(a)

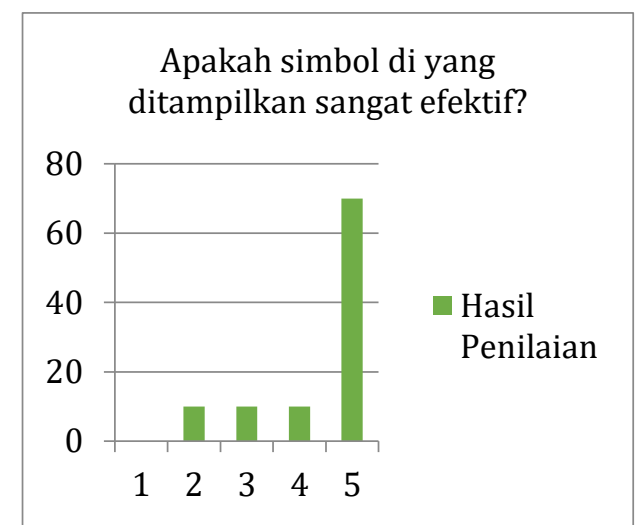

(b)

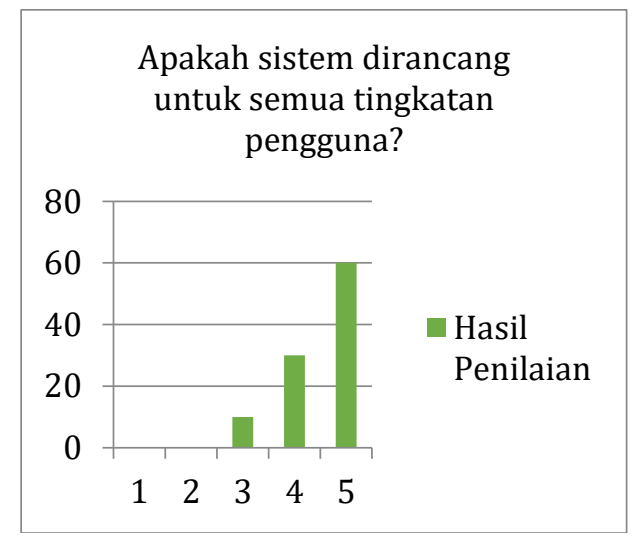

(c)

Gambar 3.17(a) Aspek pertama, (b) aspek kedua, dan (c) aspek ketiga dalam uji kejelasan arsitektural dan visual

Pada aspek pertama dilihat bahwa 100 persen dari pengguna setuju bahwa setiap halaman memiliki informasi terorganisir yang sama. Informasi utama dalam webmap ini terbagi menjadi tiga yaitu data irigasi, parameter kebutuhan air irigasi dan nilai kebutuhan air irigasi. Untuk tiap-tiap informasi disimpan seragam dan terorganisir pada tiap-tiap halaman sehingga memudahkan pengguna untuk menemukan fasilitas dan data yang diinginkan. Pada aspek kedua terlihat bahwa 70 persen pengguna setuju bahwa simbol yang ditampilkan sangat efektif. Hal ini dikarenakan pada webmap penggunaan simbol dilakukan sangat minimal dan sesuai dan fasilitas serta data yang dibutuhkan. Selain itu penggunaan warna pada data irigasi mengacu pada penelitian Cinthya Brewer (2017) sehingga pewarnaan yang dihasilkan mudah diintrepretasi oleh indera penglihatan. Pada aspek ketiga dapat dilihat bahwa 60 persen pengguna setuju bahwa sistem dapat digunakan oleh semua tingkatan pengguna. Hal ini dikarenakan dengan simbolisasi yang sederhana dan fasilitas-fasilitas yang ditampilkan di dalam webmap dibuat seragam dan konsisten sehingga mudah untuk dipahami oleh berbagai tingkatan pengguna. 
e. Kemampuan dalam data sharing

Parameter tampilanBerbagi pakai data sangat dibutuhkan untuk meminimalisir biaya yang dikeluarkan untuk mendapatkan sebuah data. Berbagi pakai data juga diperlukan untuk memaksimalkan pemanfaatan data spasial. Menurut Williamson (2001), berbagi pakai data dapat meningkatkan kualitas data dikarenakan akan banyak pihak yang akan menggunakan data sehingga apabila data tersebut memiliki kesalahan, maka akan segera diketahui.

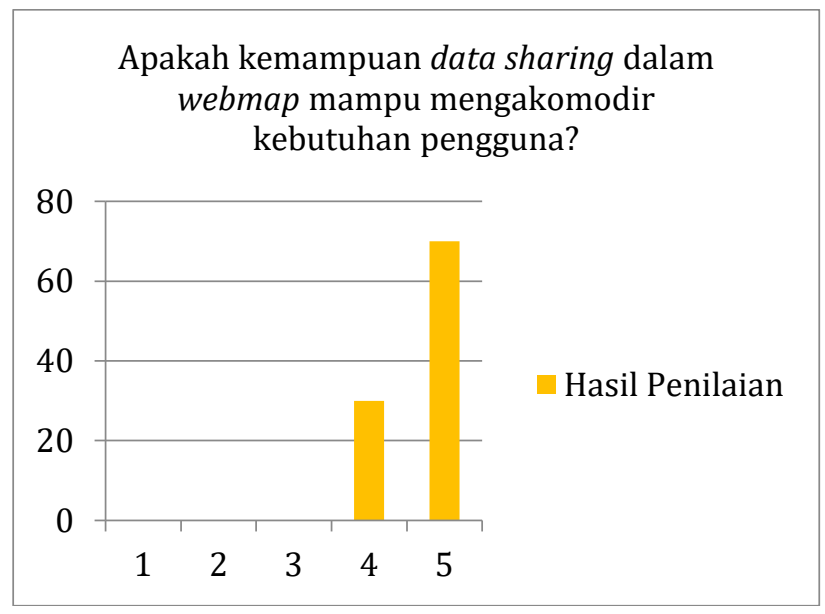

Gambar 3.18 Aspek yang diuji pada uji kemampuan data sharing

Pada aspek kemampuan data sharing 70 persen pengguna setuju bahwa fasilitas yang ada telah mengakomodir kebutuhan pengguna. Hal ini dikarenakan pengguna bukan hanya dapat melakukan penambahan dan pembaruan data irigasi maupun parameter kebutuhan air irigasi, tetapi juga dapat mengunduh data irigasi dan parameter irigasi dimana hasil unduhan yang didapat memiliki format GeoJSON. Dengan hasil yang berupa format GeoJSON pengguna dapat menggunakan data tersebut di berbagai perangkat lunak SIG, sehingga skenario tukar guna data yang terjadi semakin optimal.

\section{Kesimpulan}

Berdasarkan hasil penelitian ini diperoleh kesimpulan sebagai berikut:

1. Kebutuhan pengguna yang difasilitasi dalam sistem yaitu visualisasi data dan pencarian data kebutuhan air irigasi untuk setiap petak irigasi.

2. Tulisan ini menghasilkan sebuah rancangan sistem informasi berupa web map yang dibangun atas komponen front-end dan back-end. Komponen penyusun front-end terdiri atas HTML5, CSS, dan JavaScript dengan penambahan library Leaflet.js. Komponen penyusun back-end terdiri atas PostgreSQL dengan ditambah ekstensi PostGIS, PHP dan Apache.

3. Tulisan ini menghasilkan sebuah sistem informasi berupa web map yang diberi nama SIRISKA. Adapun fasilitas yang dapat digunakan yaitu penambahan data, pembaruan data, pembacaan data, pengunduhan data dan penghapusan data.

4. Pengujian web map dilakukan dengan uji coba langsung berdasarkan lima parameter yaitu efektivitas, kebergunaan, konsistensi, kejelasan arsitektural dan visual, dan kemampuan dalam data sharing. Pada keenam paramater yang diujikan tersebut secara keseluruhan pengguna paling tinggi berada pada nilai empat dan lima sehingga dapat disimpulkan bahwa webmap yang dibangun efektif, berguna, konsisten, memiliki kejelasan dalam arsitektur dan visual serta mampu memfasilitasi skenario tukar guna data irigasi pertanian.

\section{Referensi}

Adiyaksa, F., \& Djojomartono, P. N. (2020). Evaluasi Alih Fungsi Lahan Pertanian Menjadi Lahan Industri di Kabupaten Kendal Tahun 2014 - 2018. 3(1). Journal of Geospatial Information Science and Engineering, 3(1), 71-78. https://doi.org/10.22146/jgise.55519

Al Faruq, U. (2015). Rancang Bangun Aplikasi Rekam Medis Poliklinik Universitas Trilogi. Jurnal Informatika, 9(1), 1017-1027. https://doi.org/10.26555/jifo.v9i1.a2043

Bouman, B. a. M., Lampayan, R. M., \& Tuong, T. P. (2007). Water Management in Irrigated Rice: Coping with Water Scarcity. In International Rice Research Institute. (Issue January).

Brewer, C., \& Harrower, M. (2017). Color Brewer : Effective colour schemes for thematic maps. https://colorbrewer2.org/\#type=sequential\&schem $\mathrm{e}=\mathrm{BuGn} \& \mathrm{n}=3$

Dumas, M., \& Ter Hofstede, A. H. M. (2001). UML activity diagrams as a workflow specification language. Lecture Notes in Computer Science (Including Subseries Lecture Notes in Artificial Intelligence and Lecture Notes in Bioinformatics), 2185(April 2015), 76-90. https://doi.org/10.1007/3-540-45441-1_7

Eka, R., Rachman, A., \& Wahyu, T. (2010). Virtual Private Server (VPS ) Sebagai Alternatif Pengganti Dedicated Server. Seminar on Intelligent Technology and Its Applications, 2-7.

FAO. (2015). Sustainable Development Goals. http://www.fao.org/sustainable-development

Hansen, Israelsen, \& Stringham, G. E. (1992). Dasar-Dasar dan Praktek Irigasi (Endang (ed.)). Erlangga.

Kurnianingsih, T. N. \& Santosa, P. B. (2019). Desain Sistem Informasi Bencana Kota Semarang untuk Pengelolaan Data Bencana. Elipsoida: Jurnal Geodesi dan Geomatika, 2 (02), 53-62. https://ejournal2.undip.ac.id/index.php/elipsoida/a rticle/view/4921

Parulian, B., \& Yuliati, N. (2013). Standar perencanaan irigasi.

Paul D. Colaizzi O’Shaughnessy, S. A. D. J. H. S. R. E., \& Evans, 
R. G. (2014). Irrigation management. In Encyclopedia of Remote Sensing. Encyclopedia of Remote Sensing. https://doi.org/10.1007/978-0-387-36699-9

Rajabifard, A., \& Williamson, I. P. (2001). Spatial data infrastructures: concept, SDI hierarchy and future directions. Proceedings of GEOMATICS, April, 10. https://doi.org/10.1.1.9.1919

Santosa, P. B., Mitani, Y. \& Ikemi, H. (2010). Estimation of RUSLE EI30 based on $10 \mathrm{~min}$ interval rainfall data and GIS-based development of rainfall erosivity maps for Hitotsuse basin in Kyushu Japan. 18th International Conference on Geoinformatics, Beijing, China, 2010, pp. 1-6, https://doi.org/10.1109/GEOINFORMATICS.2010.5

\section{5}

Sudjarwadi. (1979). Pengantar Teknik Irigasi. Universitas Gadjah Mada.

United Nations. (2019). Indonesia: Volunteery National Review.

https://sustainabledevelopment.un.org/memberstat es/indonesia

Wulandari, A., \& Cahyono, B. K. (2020). Estimasi Volume Sedimentasi Waduk Sermo Menggunakan Metode RUSLE, Batimetri dan Angkutan Sedimen. Journal of Geospatial Information Science and Engineering, 3(1), 39-48. https://doi.org/10.22146/jgise.53719 